\title{
AN ANALYSIS OF SPEECH ACTS IN THE STUDENT'S TEXTBOOK AT THE SENIOR VOCATIONAL HIGH SCHOOL
}

\author{
Ni Made Ika Sukmayanthi \\ English Language Education, Universitas Pendidikan Ganesha \\ e-mail: ikasukmayanthi12@gmail.com \\ Dewa Komang Tantra \\ English Language Education, Universitas Pendidikan Ganesha \\ e-mail: dewa.komang.tantra@undiksha.ac.id \\ Made Hery Santosa \\ English Language Education, Universitas Pendidikan Ganesha \\ e-mail: mhsantosa@undiksha.ac.id
}

\begin{abstract}
The current research objectives were to analyse the eleventh grade students' textbook in the Senior Vocational High School publishes by the Indonesian Ministry of National Education based on the 2013 Curriculum. The research problems were focused on the speech acts' social functions, linguistic features, and language elements. The research was designed in a qualitative approach. Data were collected through document analysis method. Data were analysed descriptively by classifying the speech acts' social functions, linguistic features, and language elements. The research was delimited on the verbal acts or speech acts, focusing on their social functions, linguistic structures, and language features as outlined in the 2013 Curriculum (Kemdikbud 2016). The three verbal learning focus assisted students in improving their communicative competence in English. The research findings are, firstly, there were four speech act types found, namely directive, assertive, expressive, and commissive acts. The speech acts' social functions were ordering, asking, telling, advising, praying, stating, explaining, welcoming, thanking, apologizing, offering and refusing. Secondly, the speech acts' linguistic features designed were imperative, interrogative, and declarative sentences. Thirdly, the speech acts' language elements specifically grammatical rules used were simple present tense, simple past tense, present continuous tense, present perfect tense, and past continuous tense.
\end{abstract}

Keywords: speech acts, social function, linguistic features, language elements.

\section{INTRODUCTION}

Communication is the act of transferring information from one person to another which has some intentions, for examples: expressing need, desire, or perception (Lunenburg, 2010). Since communication is a tool for relating people, communication happens everywhere including in the classroom. In English as a Foreign Language (EFL) learning processes, communication is a prime tool conveyed both in oral and written forms. However, classroom communication is not running smoothly. (Huang, 2005) mentions that EFL's learning difficulties are mostly dealing with their linguistic competence. Therefore, EFL learning processes are often assisted with learning media like students' textbooks. Textbook is a media in the form of book which has intention as a tool for teaching and learning purpose (Gilbert A Valverde, 2002). Since textbook plays a significance role for the success of learning, it is 
needed to take a look and give concern to the text book. The language which is used should be clear and appropriate with the intention of the writer. One of the aspects that should be consider is the clarity of language. It will make the readers easier to convey the meaning of the sentence existed in the textbook. It is dealing with the verbal act. Verbal act is an utterance of people expressed through language (Nunan, 1993). Austin (1962) and Searle (1979) called it a speech act. A speech act is a verbal interaction which has a form, an intention and a response. The form is called a locutionary act; the intention is a illocutionary act; and, the effect or reaction is a perlocutionary act (Searle, 1979). The locutionary act is the act which is analyzed based on the surface meaning of the utterance (Cutting, 2002). The illocutionary act is the intention of saying an utterance (Austin, 1962). The outcome of research results would benefit both the EFL students and teachers as they are equipped with a good learning medium, especially an English textbook designed with speech acts' social functions, linguistic features, and language elements. These three speech acts' dimensions would provide adequate learning exposures of speech acts.

The EFL learners' failure in using speech acts correctly and appropriately is often associated with the language micro components, such as knowledge on the social functions, linguistic structures, and language features. Social functions of speech acts denote specific behaviour of an action. (Thomas, Cross-Cultural Pragmatic Failure, 1983)stated when a speaker fails to refer to specific verbal behaviour, the speaker will also fail in choosing an appropriate social function of a verbal act and will be ended by a misunderstanding. Linguistic structure is a structured formal unit system, such as a sentence and syntax. The ability to structure a sentence as subject + predicate + object + complement may change the spirit, meaning, or fluency in communication. In general, good knowledge, comprehension, and application of syntactical rules will certainly yield correct sentences (Chomsky, 1957). When a speaker communicates with a hearer, grammatical utterances will help the hearer get the locutionary acts. Language elements refer to the grammatical rules (Treisman \& Gelade, 1980) which also a crucial part in language use.

The book entitled "Bahasa Inggris" which is published by the Ministry of National Education is used by the Senior Vocational High School students in learning. It was composed based on the implementation of 2013 Curriculum $(K-13)$. The social functions of utterances that existed in the textbook were analysed using the theory of(Searle, 1979) which classified illocutionary acts into five categories, namely, directive acts, commissive acts, expressive acts, declarative acts, and assertive acts. The structures of the sentences in the textbook were analyzed based on the theory of (Seely, 2006) which divided sentence into three types namely, declarative sentence, interrogative sentence, and imperative sentence. Then, the tenses were analyzed based on twelve types of tenses namely simple present tense, present continuous tense, present perfect tense, present perfect continuous tense, simple past tense, past continuous tense, past perfect tense, past perfect continuous tense, simple future tense, future continuous tense, future perfect tense, and future perfect continuous tense (Priestley, 2008).

\section{METHOD}

The research was designed in a descriptive qualitative design (Lichtman, 2010). This research focused on describing the speech acts' social functions, linguistic features, and language elements used in the students' textbook lent by the school to accompany the EFL learning processes in the Senior Vocational High School. The data corpus was collected from the textbook called "Buku Bahasa Inggris". The speech acts types and also speech acts subtypes were determined according to the (Searle, 1979) speech act classification. The 
linguistics feature of language structures were analyzed according to (Seely, 2006)'s theory. The language element of grammatical rules were determined according to (Priestley, 2008)'s theory.

In collecting the intended data, a document analysis method was used to identify the speech acts' social functions, linguistic features, and language elements. Document analysis method was done by collecting data from the written document which support the research (Arikunto, 2006). Linguistics data were collected systematically from the textbook, which were re-written. The steps were reading the sentences contained in the textbook carefully, selecting the data from the textbook published by the Indonesia Ministry of National Education, refitting the collected data with the speech acts' classification, recording the data into data sheets, and analyzing the gathered data. The main instrument of this study was the researcher itself. To support the process, the researcher used observation sheet in the form of tables to gather the data before doing analyzation. The researcher used interactive data analysis model by (Miles \& Huberman, 1984). The steps were data reduction, data display, conclusion drawing, and verification.

\section{FINDINGS AND DISCUSSION}

There are 499 speech acts in the textbook for the eleventh grade students of the Vocational High School based on the 2013 Curriculum. The speech acts types and sub-types are functioned to complement the EFL processes in order to achieve the personal, interpersonal, and transactional communicative competence.

\section{a. The Social Functions}

In general, the speech acts designed in the students' textbook consist of 1) Directive acts (256 or $51.3 \%$ ); Assertive acts (158 or $31.7 \%$ ); Expressive acts (27 or $5.4 \%$ ); and Commissive acts ( 8 or $1.6 \%$ ). The directive acts were functioned as ordering acts, asking acts, telling acts, advising acts, and praying acts. The assertive acts were functioned as stating acts and explaining acts. The expressive acts were functioned as welcoming acts, thanking acts, and apologizing acts. Then, the commissive acts were functioned as offering acts and refusing acts.

The directive acts designed in the textbook are functioned as the following.

1) Ordering acts (141 or $28.3 \%$ ) or expressions that the speakers want the addressees to do something. For example, "With a partner, read the conversation given below!" (page 2) orders the students to read the conversation between John and Jane.

2) Asking acts (60 or 12.3\%) or expressions that the speakers want to question or ask the addressees for something. For example, "When do you want to go?"(page 2) asks Jane when she will go to watch movie with John.

3) Telling acts (53 or $10.6 \%$ ) or expressions that the speakers want to tell something to the addressees. For example, "Bullying is prevalent in our society." (page 19) tells the hearer (Siti) that bullying is a common issue that happening in society.

4) Advising acts ( 1 or $0.2 \%$ ) or expressions that the speakers want to advise or suggest the addressees about something. For example, "You should be serious about it as well." (page 19) advises the hearer to take more attention toward the issue.

5) Praying acts ( 1 or $0.2 \%$ ) or expressions that the speakers pray or wish for something. For example, "Have a nice flight!" (page 12) wishes the safe and nice flight for the passenger.

The assertive acts are functioned as the following.

1) Stating acts (110 or $22.2 \%$ ) or expressions that the speakers want to state something toward the addressees. For example, "I don't agree with you." (page 19) states that Siti does not agree with Jane's opinion. 
2) Explaining acts (48 or $9.7 \%$ ) or expressions that the speakers want to explain something toward the addressees. For example "An exposition text needs to clearly state the point of view, use valid research findings to support your viewpoint, defend your viewpoint, support the viewpoint with factual data like graphs, pictures, charts." (page 48) explains to the readers that there are several things to be concerned in writing exposition text, such as the clear point of view, valid research finding, some supporting evidences for the point of view.

The expressive acts are functioned as the following.

1) Welcoming acts (19 or 3.8\%) or expressions that is used by the speakers for welcoming the addressees. For example, "Hello!" (page 62) welcomes Siti by greeting.

2) Thanking (7 or 1.4\%) or expressions that is used by the speakers for thanking the addressees. For example, "Thank you!" (page 3) thanks Jane for offering help.

3) Apologizing ( 1 or $0.2 \%$ ) or expressions that is used by the speakers for asking apology toward the addressees. For example, "I am so sorry, please forgive me." (page 62) apologizes Siti for replying the letter after a long time.

The commissive acts are functioned as the following.

1) Offering acts (6 or 1.2\%) or expressions for the speakers offer something to the addressees. For example, "Would you like to go to movies?" (page 2) offers John to go watching movie together.

2) Refusing acts ( 2 or $0.4 \%$ ) or expressions for rejecting the action that proposed by the addressees. For example, "I would love to, but not right now." (page 2) refuses Jane's invitation to go to movies.

In summary, the speech acts' social functions designed in the textbook for the eleventh grade students at the Senior Vocational High School are: 1) directive acts functioned as ordering acts, asking acts, telling acts, advising acts, and praying acts; 2) assertive acts functioned as stating acts and explaining acts; 3 ) expressive acts functioned as welcomingg acts, thanking acts, and apologizing acts; and 4) commissive acts functioned as offering acts and refusing acts.

The speech acts' social functions imply the necessity to add other speech act types and sub-types as theorized by (Searle, 1979), particularly the declarative speech acts in the student textbook in order to develop the students' complete communicative competence, especially on personal, interpersonal, and transactional verbal communications. The speech act sub-types are also important to be included in the textbook in order to give full exposures to native-like verbal interactions using the speech act sub-types.

\section{b. The Linguistic Features}

Linguistic feature concerns with a structured system of a formal unit such as sentences and syntax (Leech, 1989). An example of explicit order, "You go out!" This command is ordered with a subject "You", a predicate "go out". Another example of a polite request, "Please, lend me your pen". It is apparently structured with a polite marker "Please"; predicate "lend"; an indirect object "me'; and a direct object "your pen". The speech acts' linguistic features or sentence patterns designed in the students' textbook for the eleventh grade of the Senior Vocational High School were: 1) imperative sentence, 2) interrogative sentence, and 3) declarative sentence.

1) Directive Acts' Linguistic Features

(1)Ordering act is structured as follows, "With a partner, read the conversation given below!" (page 2) is an imperative sentence structured using a sentence pattern: Complement (with a partner) + Predicate (read) + Object (the conversation given below). 
(2)Asking act is structured as follows, "When do you want to go?"(page 2) is an interrogative sentence structured using a sentence pattern: Predicate (when do want) + Subject (you) + Predicate (to go) + Question mark (?)

(3)Telling act is structured as follows, "Bullying is prevalent in our society." (page 19) is a declarative sentence structured using a sentence pattern: Subject (bullying) + Predicate (is prevalent) + Compliment (in our society)

(4)Advising act is structured as follows, "You should be serious about it as well." (page 19) is a declarative sentence structured using a sentence pattern: Subject (you) + Predicate (should be serious) + Compliment (about it as well)

(5)Praying act is structured as follows, "Have a nice flight!" (page 12) is a declarative sentence structured using a sentence pattern: Predicate (have) + Object (a nice flight)

2) Assertive Acts' Linguistic Features

(1)Stating act is structured as follows, "I don't agree with you." (page 19) is a negative declarative sentence structured using a sentence pattern: Subject $(I)+$ Predicate $($ don't agree with) + Object (you)

(2)Explaining act is structured as follows, "The fourth line is the occasion for invitation." (page 34) is a declarative sentence structured using a sentence pattern: Subject (the fourth line) + Predicate (is) + Object (the occasion for invitation).

3) Expressive Acts' Linguistic Features

(1)Welcoming is structured as follows, "Hello!" (page 62) is a declarative sentence structured using a sentence pattern: Exlamation word (hello)

(2)Thanking act is structured as follows, "Thank you!" (page 3) is a declarative sentence structured using a sentence pattern: Predicate (thank) + Object (you)

(3)Apologizing act is structured as follows, "I am so sorry." (page 62) is a declarative sentence which is structured using a sentence pattern: Subject $(I)+$ Predicate (am so sorry).

4) Commissive Acts' Linguistic Features

(1) Offering act is structured as follows, "Would you like to go to movies?" (page 2) is an interrogative sentence which is structured using a sentence pattern: Predicate (would like - to go to $)+$ Subject (you) + Object (movies) .

(2) Refusing act is structured as follows, "I would love to, but not right now." (page 2) is a negative declarative sentence structured using a sentence pattern: Subject $(I)+$ Predicate (would love to) + Complement (not right now).

The second research finding on the speech acts' linguistic feature simply the need to teach and train EFL learners on sentence types like declarative sentences, interrogative sentences, and imperative sentences. The sentence structures such as simple, compound, complex, and complex-compound sentences are needed to be taught in order to facilitate the students' communicative competence. Sentence type and structure provide the EFL learners with the framework for the clear written expression of ideas. In writing is always expected to write complete and correct sentences which are correctly punctuated. A complete sentence always contains a verb, expresses a complete idea and makes sense standing alone.

\section{c. The Language Elements}

The speech acts' language elements used in the textbook for the eleventh grade students at the Senior Vocational School were as follows.

1) Directive acts' tenses consist of a) simple present tense, b) present continuous tense c) simple past tense d) present perfect tense, and e) past continuous tense. These are some of the sentences expressed in the textbook:

a. "With a partner, read the conversation given below!" (page 2) is a directive act in the form of affirmative imperative sentence and expressed in the simple present tense. 
b. "When do you want to go?"(page 2) is sentence that expressed using simple present tense.

c. "What are you doing?" (page 75) is expressed in present continuous tense.

d. "Did you know?" (page 36) is using simple past tense.

e. "You have a point, but have you ever thought how poor people on the street feel?" (page 26). This sentence is expressed using present perfect tense.

f. "Mum was making sure that we didn't miss any sight of the whole city, so we had practically been everywhere." (page 62) is expressed in past continuous tense.

2) Assertive acts' tenses consist of a) simple present tense, b) present continuous tense, c) simple past tense, and d) present perfect tense. These are some of the sentences expressed in the textbook:

a. "I don't agree with you." (page 19) this sentence is expressed in simple present tense.

b. "You are getting too serious!" (page 19) uses present continuous tense.

c. "The text was easy to understand." (page 60). This sentence uses simple past tense.

d. "A recent study has shown that due to unpredictable weather patterns, there have been lot of failed crops." (page 46) This sentence use present perfect tense.

3) Expressive acts' tenses consist of a) simple present tense.

a. "Hello!" (page 62) is a sentence which uses simple present tense.

4) Commissiveacts's tenses consist of a) simple present tense.

a. "Would you like to go to movies?" (page 2). This sentence uses simple present tense.

The third finding was on the speech acts' language elements, especially the tenses. The tenses are the most important part of English language. If one wishes to communicate, or wish to say anything to anyone, he/she needs to express the idea in the right form of tenses. There are three major tenses, they are, present tenses (the simple present tense, present continuous tense, present perfect tense, present perfect continuous tense), past tenses (the simple past tense, past continuous tense, past perfect tense, past perfect continuous tense), and future tenses (the simple future tense, future continuous tense, future perfect tense, future perfect continuous tense). The mastery on the English tenses implies to the EFL learners' productive oral and written skills in English.

\section{CONCLUSION AND SUGGESTIONS}

The speech acts' social functions designed in the textbook for the eleventh grade students at the Senior Vocational High School consisted of directive acts, assertive acts, expressive acts, commissive acts. The speech acts' linguistic features or sentence patterns designed in the students' textbook were imperative sentence, interrogative sentences, and declarative sentences. While the speech acts' language elements or grammatical rules used simple present tense, simple past tense, present continuous tense, present perfect tense and past continuous tense.

Based on the result of study, it is suggested to the EFL teacher to supplement those speech act types and sub-types in the learning processes in order to train EFL learners' complete pragmatic competence. Then, the EFL teachers are also suggested to integrate sentence types like declarative, interrogative, and imperative sentences in the teaching of listening, speaking, reading and writing skills. The sentence structures such as simple, compound, complex, and complex-compound sentences also suggested to be integrated in those four skills as to provide the EFL learners with the framework for the clear written expression of ideas. And do not forget to integrate the right form of tenses so that the EFL learners could express their ideas in the right form of tenses. When the EFL learners mater the correct form of tenses and their usages, they will certainly be competent in producing oral and written skills in English. 


\section{REFERENCES}

Austin, J. (1962). How to do Things with Words. Oxford: Oxford University Press.

Chomsky, N. (1957). Syntactic Structures. Mouton \& Co.

Cutting, J. (2002). Pragmatics and Discourse. London and New York: Routledge.

Gilbert A. Valverde, L. J. (2002). According to the Book: Using TIMSS to investigate the translation of policy into practice through the world of textbooks. London: Kluwer Academic Publisher.

Huang, J. (2005). A Diary Study of Difficulties and Constraints in EFL Learning. Elsevier.

Leech, G. (1989). Principles of Pragmatics. London : Longman.

Lichtman, M. (2010). Qualitative Research in Education: A User's Guide. 2nd Edition. California: Sage.

Lunenburg, F. C. (2010). Communication: The Process, Barriers, And Improving Effectiveness. Schooling, 1.

Nunan, D. (1993). Introducing Discourse Analysis. London: Penguin.

Priestley, J. (2008). The Rudiments of English Grammar, 1761. Michigan: Scolar P., 1969.

Searle, J. (1979). Expression and Meaning: Studies in the Theory of Speech Acts. London: Cmbridge University Press.

Thomas, J. (1983). Cross-Cultural Pragmatic Failure. Applied Lingustics. 